\title{
Retazos de África Una mirada a la historia reciente de Ruanda
}

\section{Cuenta la leyenda}

"Imana, Dios de las colinas, buscaba a quién confiar sus rebaños de vacas. Una tarde descendió a su tierra preferida confío a los tres ilustres las tres razas de Ruanda una taza de leche. Gatua era el padre de los batuas, Gahutu el padre de los hutus, Gatutsi era el precursor de los tutsis. Posteriormente Imana retorna a su imperio celestial, y al final de la noche ancestral, quiere verificar qué es lo que los tres notables han hecho con su jarra de leche. Al salir de su colina, Gahutu había tenido sed, bebí́ pues la leche y se recostó. Al alba, cuando los pequeños terneros comenzaban a desperezarse, Gatua se debatía en un sueño agitado, e involuntariamente volcó la jarra y la tierra bebió su leche Imana buscó a Gatutsi y lo encontró en cuclillas velando su jarra de leche. Cuando se percató de la presencia de Imana, Gatutsi se apresuró a destapar la jarra, como exigen las costumbres ancestrales, ya que presentarla tapada sería un insulto. Imana le cuestiona: "¿no te gusta mi leche? - Sí, señor. Pero yo he pensado que tú regresarías a Ruanda y que posiblemente tendrías sed. Por esto la ha guardado para tí. Bebe señor". Entonces Imana dijo a Gatutsi: "Ganza reine...".

Las categorías de hutu y tutsi entrañan, más que la designación de una raza determinada, una casta o una categoría moral. Así, en el pasado, cuando un tutsi sostenía un mal comportamiento, podía inmediatamente pasar a ser tratado como hutu; y a la inversa, un hutu que se destacaba o que poseía un número determinado de vacas, era ascendido a Tutsi. Sin embargo, estas chiquitas aunque trascendentales peculiaridades de una cultura en la que rigen mecanismos diferentes a la nuestra, fueron ignoradas por alemanes y belgas cuando arribaron al "país de la mil colinas".

* La autora, geógrafa de formación, es de origen español y centroamerica de adopción. Ha trabajado en proyectos para distintos proyectos humanísticos en Nicaragua, El Salvador, Haití y Ruanda. En la actualidad se encuentra en Haití. 


\section{Cuenta la realidad...}

Ruanda, con una extensión similar a la de Bélgica y la densidad de población más alta de África, contaba antes de los terribles acontecimientos de abril de 1994 con 7.736 .000 habitantes. Para hacer un breve recorrido por la historia de esta país digamos que en 1961 se proclama la república ruandesa, con Gregoire Kayibanda como primer presidente. Previo a esta proclamación había tenido lugar, en noviembre de 1959, una revolución social y política, la "toussaient" ruandesa, que trajo como consecuencia al asesinato de decenas de millares de tutsis. Entre 1959 y 1963 alrededor de 200,000 tutsis se exiliaron en Uganda, Burundi y Zaire. Estos exiliados constituyen los refugiados más antiguos del continente africano.

En octubre de 1990, con Juvenal Habyarimana como presidente, el Frente Patriótico Ruandés ataca desde la frontera de Uganda, acción que es contestada al interior del país con la masacre de Kibilira. Más adelante, en 1992, se suceden otras masacres de tutsis, conocidas como la de Bugesera, Kibuye y Gisenyi. En febrero de 1993, un mes después de la firma de los acuerdos de Arusha, cerca de un millón de campesinos abandonan el norte huyendo hacia Kigali.

A partir del 13 de julio de 1994 comienza el éxodo masivo de ruandeses en dirección a los países vecinos, sobre todo al Zaire. Sin que se pueda precisar la cifra, tras el genocidio ruandés, entre $1,700,000$ y 2,000,000 personas abandonan el país, sus viviendas, sus cosechas, sus escuelas, todo su entorno sin mirar atrás siquiera.... buscando borrar de su memoria unas imágenes que jamás habrían podido imaginar, en la mayoría de los casos sin llegar a conseguirlo.

\section{III. ¿Será posible la reconciliación de este pueblo?}

De los supervivientes de este genocidio, que constituye en términos cuantitativos el tercero en la historia de la humanidad después del de los armenios y del de los judíos pero el primero entre pueblos de la misma ascendencia, la ruandesa, común a hutus y tutsi, el sector más vulnerable lo constituyen los niños, los cuales salieron, en el mejor de los casos, cargados en la espalda de su madre o hermana, atados al estilo ruandés. Otros salieron caminando kilómetros y kilómetros a pesar de su corta edad, siguiendo las filas ingentes de personas que huían porque sus familias habían sido totalmente diezmadas.

Hace unas semanas, conocí la historia de uno de nuestros colaboradores. Alamb, hijo de la entonces principal autoridad judicial de la segunda ciudad del país me la relató. Ocurrió que la familia tenía la visita de un grupo de familiares que eran acogidos de acuerdo al ancestral protocolo de hospitalidad ruandesa. Se hallaban conversando y riendo alegremente cuando sonó el timbre de la puerta y algo se quebró en el ambiente. Varios entraron y redujeron a su padre, exigiendo una cantidad de dinero imposible de tener al alcance de la mano, por lo que 
todos quedaron retenidos a la espera de conseguirlo. Pasaron cuatro días, tan largos como cuatro meses hasta que al fin se pudo reunir la cantidad exigida.

Parecía que la distención volvía al hogar cuando uno de los armados les pidió que salieran al patio posterior. Cuando todos hubieron salido comenzó el tiroteo indiscriminado a adultos, y jóvenes y niños. Eran unas imágenes inenarrables. Alamb consiguió a duras penas escapar al tiroteo y saltar la tapia. De allí corrió como jamás lo había hecho hasta la vivienda de uno de sus mejores amigos de ascendencia hutu, donde esperó hasta poder hablarle en privado, para evitar así comprometer a los demás miembros de la familia. A la sombra de su amigo, comiendo ya entrada la noche cuando todos dormían, apostado durante horas en el techo, pasó varios meses hasta que pudo salir y refugiarse en Burundi.

Su cabeza estaba como el mar bajo la más recia tormenta: ¿dónde habrían quedado los cadáveres? ¿algún familiar habría sobrevivido? y si así fuere ¿lo habrían podido socorrer?... Alamb fue uno de los primeros en tomar la decisión de regresar a su país. Sencillamente su corazón estallaba. Ya no podía más. Después de tediosas investigaciones logró averiguar que un alma solidaria había conseguido sacar a su hermana menor que, aunque herida, logró salir fuera del faís. Al menos otra persona de su familia estaba viva. Comenzó a indagar sin descanso, a visitar fosas donde se pudieran hallar los restos de su familia. Sus energías ya no resistían posponer por más tiempo la ceremonia de enterramiento. Este proceso fue tan complejo como largo e infructuoso, pero más de dos años después creyó estar sobre la pista correcta: había hallado una manga de la camisa de su padre aunque ¿cómo podía recuperar sus retos en medio de una fosa común en la que habían sido arrojados centenares de cuerpos?

Esta es una pequeña muestra del drama de los conocidos como "rescapes", personas que lograron salvarse del genocidio y a quienes aparte de las secuelas psicológicas personales, les ha quedado la vulnerabilidad de los perseguidos por haber sido un día testigos oculares de masacres a diferente escala. El drama de los rescapes es más penoso, si cabe, en las áreas rurales que en las ciudades donde uno puede pasar desapercibido con mayor facilidad. En el campo se da la situación de tener que agruparse y esconderse a la salida del sol, agregando al terror đe lo vivido el terror de correr la misma suerte. ¿Será posible el perdón y la reconciliación en estos casos?

\section{A la espera del juicio}

Gitarama, la tercera provincia del país, está dividida administrativamente en diecisiete comunas. Cada uno de los miembros de nuestro equipo trabaja en tres o cuatro de ellas. Hoy me ha tocado una visita habitual. Subimos y bajamos montañas, no hay que olvidar que este país ha sido bautizado como "la Suiza de ÁFRICA. Las múltiples tonalidades verdosas me recuerdan mi tierra natal, así 
como la abundancia de eucaliptos, pero las bananeras, las palmeras, la pitas, me llevan de nuevo a mi querida Centroamérica. Los cactus gigantes que semejan frondosos árboles de tres o cuatro metros de altura son nuevos para mí. El ordenamiento de los cultivos nos llama verdaderamente la atención. Los campesinos hacen gala de un excelente equilibrio para efectuar sus siembras. Equilibrio para vivir, equilibrios para sobrevivir a su propia realidad.

Llegamos a la comuna, al pequeño edificio que sería el equivalente de la Alcaldía. El entorno luce lleno de colorido, de curiosas combinaciones de estampados de los "tissus" femeninos y de niños de diferentes edades, desde bebés apostados a las espaldas del $70 \%$ de las mujeres, ya sean sus madres, hermanas o abuelas, hasta los que hacen fila a la puerta de la prisión para llevar comida a algún familiar. Los varones están en minoría, lo cual no extraña a nadie, dada la cantidad de muertos, de refugiados en el exterior y de los que se hallan privados de la alegría de contemplar estos cielos esplendorosamente azules, confinados como están entre rejas.

Precisamente lo que está previsto en mi programa del día es una visita a estas celdas, tan diferentes a las de los países "desarrollados", me atrevería a decir tan diferentes a lo que cualquiera puede entender por celdas. Antes de entrar hay que pasar las formalidades de rigor, las entrevistas protocolarias con las autoridades civiles y militares. Después de los trámites las puertas, que sólo se abren un par de veces diariamente - para permitir a los presos salir a las letrinas y para recibir la comida del día - ceden de manera extra para permitirnos la entrada. Algunos de mis compañeros consideran que estas visitas hay que hacerlas cuando uno lleva al menos un mes en el país, otros dicen que pudiera considerarse como la prueba de fuego que hay que pasar en los primeros días.

La superpoblación de las prisiones ruandesas después del genocidio es un tema bastante conocido. Cuando se leen informaciones como que "las salas albergan el triple de los detenidos de lo que sería su capacidad", cualquier mortal podría imaginarse que si es así el espacio entre las camas debe de ser mínimo, o que las literas deben semejar rascacielos neoyorkinos. Pero no, no existen ni literas, ni camas, ni colchones ni nada que evoque siquiera a un tímido petate. Recuerdo que al siguiente día de mi llegada a esta región, escuché que varios detenidos tenían problemas en las piernas. En medio de esa ingenuidad que siempre me acompaña, pensé que se podía deber a las características del clima de montaña y no hice más preguntas. Cuando visité la primera celda comprendí inmediatamente la causa, no puede ser de otra manera cuando un ser humano debe pasar la mayor parte del día o bien de pie o bien sentado, y cuando la llegada de la noche no implica ningún cambio de posibilidades. $Y$ así meses y meses. ¿Ampliación, construcción de prisiones o agilización de dossiers y de juicios? La respuesta queda para el corazón y el raciocinio de los lectores de estos y otros retazos. 
En mi segunda visita me, pareció una contribución más a las injusticias mundanas el hecho de que aún se encogieran un poco más para darme cabida en el centro de la sala. Pero lo que tardaré en olvidar es el orden y la disciplina absoluta de las 164 personas que había en la primera de las celdas. Nos es sumamente difícil imaginar que éstos detenidos que ahora tengo a mi alrededor - bien es cierto que en circunstancias bien distintas - hayan sido protagonistas del genocidio de 1994. Pareciera, en ese momento, que las normas de conducta y el respeto que sus antepasados se encargaron de trasmitir de generación en generación, permanecen incólumes. ¿Será esta misma disciplina la que les llevó a obedecer a sus superiores cuando emitieron la orden de "exterminar", "cortar el árbol desde su raíz... que no quede ningún niño tutsi, para no caer en los errores del pasado".

\section{V. ¿Esperanza del futuro o perpetuación del presente?}

Los niños, ese bagaje contemplado como la esperanza del país. Estos que nos miran con ojos sorprendidos, los únicos de los que fácilmente obtenemos pronta sonrisa. ¿Lograremos sembrar en sus corazones el espíritu de reconciliación a través de la promoción de los derechos humanos? Si fuera así, habríamos hecho algo.

Ayer en el orfelinato se nos hizo un nudo en la garganta. Algunos de nosotros presumimos de experiencia, de haber vivido muchos de esos momentos de absurdo en países "en vías de desarrollo". Algunos dicen "estar de vuelta de todo" y, en estos casos, yo pienso que no hay nada más lejos de la realidad, pues el mundo de lo inconcebible desgraciadamente sigue abierto. Alguien había llevado unos dulces a los niños y se los estaba repartiendo. Un chavalo de seis o siete años llegó corriendo de fuera y estirando su manita minúscula dijo en kinyaruanda: "dame, que yo también maté a dos bebés...". La educadora sólo apartó la mirada. Nosotros le pedimos a uno de los niños mayores que nos hiciera el favor de traducir lo que había expresado el niño. Ella se había negado a hacerlo.

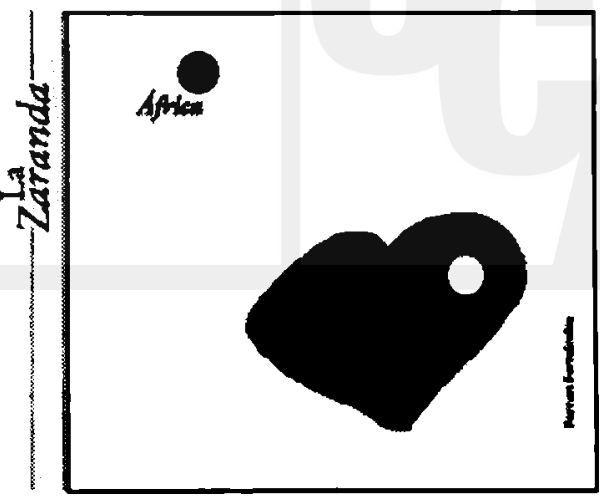

